\title{
Desulfurispira natronophila gen. nov. sp. nov.: an obligately anaerobic dissimilatory sulfur-reducing bacterium from soda lakes
}

\author{
D. Y. Sorokin • G. Muyzer
}

Received: 2 March 2010/Accepted: 7 April 2010/Published online: 21 April 2010

(C) The Author(s) 2010. This article is published with open access at Springerlink.com

\begin{abstract}
Anaerobic enrichment cultures with elemental sulfur as electron acceptor and either acetate or propionate as electron donor and carbon source at $\mathrm{pH} 10$ and moderate salinity inoculated with sediments from soda lakes in Kulunda Steppe (Altai, Russia) resulted in the isolation of two novel members of the bacterial phylum Chrysiogenetes. The isolates, AHT11 and AHT19, represent the first specialized obligate anaerobic dissimilatory sulfur respirers from soda lakes. They use either elemental sulfur/polysulfide or arsenate as electron acceptor and a few simple organic compounds as electron donor and carbon source. Elemental sulfur is reduced to sulfide through intermediate polysulfide, while arsenate is reduced to arsenite. The bacteria belong to the obligate haloalkaliphiles, with a $\mathrm{pH}$ growth optimum from 10 to 10.2 and a salt range from 0.2 to $3.0 \mathrm{M} \mathrm{Na}^{+}$(optimum 0.4-0.6 M). According to the phylogenetic analysis, the two strains were close to each
\end{abstract}

Communicated by A. Oren.

Electronic supplementary material The online version of this article (doi:10.1007/s00792-010-0314-7) contains supplementary material, which is available to authorized users.

The GenBank/EMBL accession number of the 16S rRNA gene sequences of strains AHT1 $11^{\mathrm{T}}$ and AHT19 are GQ922842 and GQ922843, respectively.

D. Y. Sorokin $(\varangle) \cdot$ G. Muyzer

Winogradsky Institute of Microbiology,

Russian Academy of Sciences, Prospect 60-let Octyabrya 7/2,

Moscow 117811, Russia

e-mail: soroc@inmi.host.ru; d.sorokin@tudelft.nl

D. Y. Sorokin · G. Muyzer

Environmental Biotechnology Group,

Department of Biotechnology,

Delft University of Technology, Delft, The Netherlands other, but distinct from the nearest relative, the haloalkaliphilic sulfur-reducing bacterium Desulfurispirillum alkaliphilum, which was isolated from a bioreactor. On the basis of distinct phenotype and phylogeny, the soda lake isolates are proposed as a new genus and species, Desulfurispira natronophila (type strain $\mathrm{AHT} 11^{\mathrm{T}}=$ $\mathrm{DSM} 22071^{\mathrm{T}}=$ UNIQEM $\mathrm{U}^{2} 58^{\mathrm{T}}$ ).

Keywords Desulfurispirillum alkaliphilum .

Haloalkaliphilic · Soda lakes .

Sulfur-reducing bacteria (SuRB)

\section{Introduction}

The first haloalkaliphilic sulfur-respiring bacterium described as Desulfurispirillum alkaliphilum has recently been isolated from a full-scale bioreactor removing sulfide from biogas (Sorokin et al. 2007). In this anthropogenic system a short sulfur cycle at moderately haloalkaline conditions apparently takes place, i.e., sulfide oxidation to elemental sulfur at oxygen limitation as the main process and sulfur reduction at the expense of organic carbon excreted by the sulfide oxidizers as a minor unwanted reaction (Janssen et al. 2009).

Investigation of the reductive branch of the sulfur cycle (i.e., sulfidogenesis) at extremely haloalkaline conditions has so far been limited by dissimilatory sulfate reduction, which demonstrated that this process is very active in soda lake habitats and that novel lineages within the Deltaproteobacteria are responsible for this activity (Gorlenko et al. 1999; Sorokin et al. 2004; Scholten et al. 2005; Kulp et al. 2006; 2007; Foti et al. 2007; Zhilina 2007; Sorokin et al. 2008a). Until now, only a single report has been published on the presence of non sulfate-reducing sulfidogenic 
haloalkaliphiles in soda lakes (Sorokin et al. 2008b). Meanwhile, the existence of short sulfur cycling similar to the example mentioned above might be predicted for the conditions of shallow hypersaline soda lakes, where sediments have high sulfide content at the top and low oxygen solubility in near bottom brines. One of the most interesting features of sulfur speciation at high $\mathrm{pH}$ is the appearance of linear polysulfide $\left({ }^{-} \mathrm{S}-\mathrm{S}_{x}-\mathrm{S}^{-}\right)$as a stable intermediate, which, in contrast to cyclic elemental sulfur, is soluble, and, therefore, much more reactive. Polysulfides are the products of spontaneous reaction of sulfide and elemental sulfur. This makes sulfur cycling at high $\mathrm{pH}$ and, particularly, dissimilatory sulfur reduction where polysulfide is the actual electron acceptor (Hedderich et al. 1999), substantially different from those in the $\mathrm{pH}$-neutral marine habitats.

Here we describe the properties of two novel obligately anaerobic bacterial isolates from hypersaline soda lakes in south-west Siberia, which represent the first highly specialized haloalkaliphilic dissimilatory sulfur/polysulfide reducers. The most important function of these bacteria is the potential to utilize acetate as electron donor with sulfur as electron acceptor at extremely haloalkaline anoxic conditions.

\section{Methods}

\section{Samples}

Samples of the top $5 \mathrm{~cm}$ sediments from soda lakes Tanatar-5 $\left(\mathrm{pH}=10.15\right.$; salinity $=80 \mathrm{~g}^{-1}$; total alkalinity $=0.98 \mathrm{M} ; \mathrm{HS}^{-}=2.0 \mathrm{mM}$; July 2008) and Cock Soda Lake $\left(\mathrm{pH}=10.3\right.$; salinity $=120 \mathrm{~g} \mathrm{l}^{-1}$; total alkalinity $=0.82 \mathrm{M} ; \mathrm{HS}^{-}=0.50 \mathrm{mM}$; July 2009) were used to enrich for sulfur-respiring haloalkaliphiles.

\section{Enrichment and cultivation of SuRB}

Enrichment and routine cultivation of haloalkaliphilic $\mathrm{SuRB}$ was performed at $28^{\circ} \mathrm{C}$ on a mineral medium containing sodium carbonate buffer $\left(0.5 \mathrm{M} \mathrm{Na}^{+}\right)$with $\mathrm{pH} 10$, $0.1 \mathrm{M} \mathrm{NaCl}$, and $0.5 \mathrm{~g} \mathrm{l}^{-1}$ of $\mathrm{K}_{2} \mathrm{HPO}_{4}$. After sterilization in closed bottles, the medium was supplemented with either $20 \mathrm{mM}$ acetate or propionate as carbon and energy source, $20 \mathrm{mg} \mathrm{l}^{-1}$ of yeast extract, $4 \mathrm{mM} \mathrm{NH}_{4} \mathrm{Cl}, 1 \mathrm{mM} \mathrm{MgSO}_{4}$, $1 \mathrm{ml} \mathrm{l}^{-1}$ each of acidic trace metal solution and vitamin mix (Pfennig and Lippert 1966) and $1 \mathrm{ml}^{-1}$ of alkaline $\mathrm{Se} / \mathrm{W}$ solution (Plugge 2005). Elemental sulfur (Fluka) was autoclaved as a thick water paste at $110^{\circ} \mathrm{C}$ for $40 \mathrm{~min}$ in closed bottles and added in excess of approximately $3 \mathrm{~g} \mathrm{l}^{-1}$. Other electron acceptors used were $\mathrm{KNO}_{3}$ and $\mathrm{Na}_{2} \mathrm{~S}_{2} \mathrm{O}_{3}$ (20 mM each), $\mathrm{KNO}_{2}, \mathrm{Na}_{2} \mathrm{SO}_{3}$, sodium selenate and selenite, sodium arsenate, DMSO (5 mM each), sodium fumarate $(20 \mathrm{mM})$, and freshly prepared amorphous ferrihydrite $(20 \mathrm{mM})$. The latter was prepared by mixing 1:1 $0.5 \mathrm{M}$ solution of $\mathrm{FeCl}_{3}$ and $1 \mathrm{M} \mathrm{NaOH}$ with subsequent washing of the precipitate with distilled water until neutral $\mathrm{pH}$ reaction. In all cases, except for the latter, $1 \mathrm{mM} \mathrm{HS}^{-}$was added to the medium as a reductant. Growth at micro-oxic conditions was tested with an oxygen concentration in the gas phase of $1 \%$. Routine cultivation was performed either in $15 \mathrm{ml}$ Hungate tubes with $10 \mathrm{ml}$ medium, or in $50 \mathrm{ml}$ serum bottles with $40 \mathrm{ml}$ medium with argon in the gas phase. The $\mathrm{pH}$ dependence was examined at $\mathrm{Na}^{+}$content of $0.6 \mathrm{M}$, using the following filter-sterilized mineral medium: for $\mathrm{pH}$ 6-8, 0.1 M HEPES and $\mathrm{NaCl} / \mathrm{NaHCO}_{3}$; for $\mathrm{pH} 8.5-11$, a mixture of sodium bicarbonate/sodium carbonate containing $0.1 \mathrm{M} \mathrm{NaCl}$. To study the influence of salt concentration on growth, sodium carbonate media with $\mathrm{pH} 10$, containing 0.1 and $3.5 \mathrm{M}$ of total $\mathrm{Na}^{+}$were mixed in different proportions.

\section{Analytical procedures}

Free sulfide and the sulfane moiety of polysulfide were measured colorimetrically (Trüper and Schlegel 1964) after precipitation in $10 \%(\mathrm{w} / \mathrm{v}) \mathrm{Zn}$ acetate. The internal sulfur of the polysulfide was separated by acidification of the sample to $\mathrm{pH}<3$ with concentrated $\mathrm{HCl}$, then precipitated by centrifugation, washed with distilled water, dried, extracted from the cell pellet with acetone overnight and assayed by a cyanolytic procedure (Sörbo 1957). Cell protein was determined according to Lowry et al (1951) after removal of sulfide/polysulfide and washing the cell pellet several times with $0.6 \mathrm{M} \mathrm{NaCl}$. Arsenite was detected by anionic chromatography after neutralization of the supernatant using Biotronic chromatograph, anionexchange column BT11AN, and $1 \mathrm{mM} \mathrm{Na} \mathrm{CO}_{3} / 1.2 \mathrm{mM}$ $\mathrm{NaHCO}_{3}$ as eluent with a flow rate of $1.5 \mathrm{ml} \mathrm{min}$. Acetate was analyzed in filtrated supernatant after acidification to $\mathrm{pH} 4$ by anionic chromatography (Biotronic IC-1000, Germany; column BT III OS; conductivity

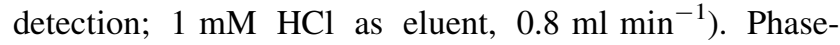
contrast microphotographs were obtained with a Zeiss Axioplan Imaging 2 microscope (Göttingen, Germany). For electron microscopy, the cells were negatively contrasted with $1 \%(\mathrm{w} / \mathrm{v})$ neutralized phosphotungstate. Polar lipids were extracted from $50 \mathrm{mg}$ of freeze dried cells with acidic methanol and the fatty acid methyl esters were analyzed by GC-MS according to Zhilina et al. (1997).

Genetic and phylogenetic analysis

The isolation of the DNA and determination of the $\mathrm{G}+\mathrm{C}$ content of the DNA was performed according to Marmur 
(1961) and Marmur and Doty (1962), respectively. For molecular analysis, the DNA was extracted from the cells using alkaline SDS lysis at $60^{\circ} \mathrm{C}$ and purified with the Wizard Preps Kit (Promega, USA). The nearly complete 16S rRNA gene was obtained using general bacterial PCR primers 11f and 1492r (Lane 1991). The sequences were aligned with sequences from the GenBank using CLUSTAL $\mathrm{W}$ and the phylogenetic tree was reconstructed using neighbor-joining algorithm in the TREECONW program package (van de Peer and de Wachter 1994).
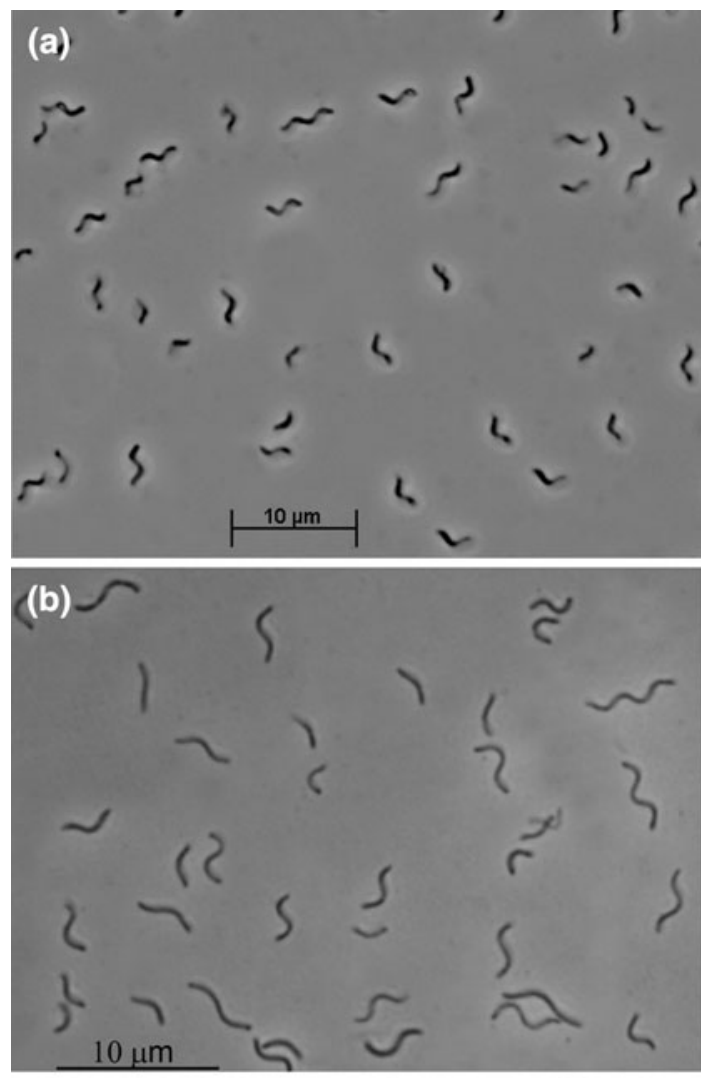

(c)

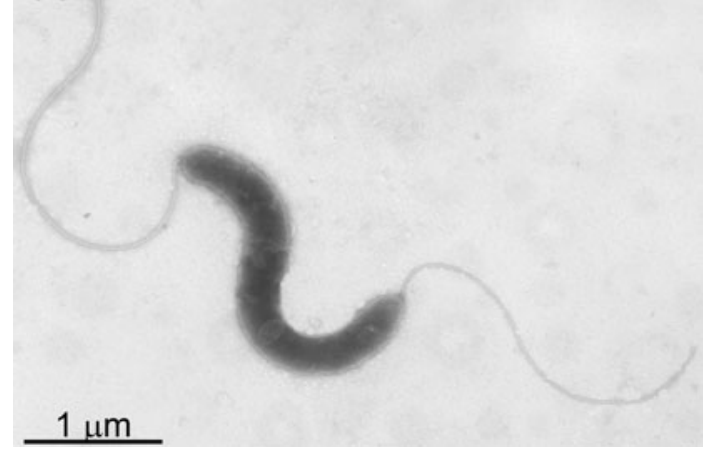

Fig. 1 Morphology of sulfur-reducing isolates. a and b phasecontrast microphotograph of cells of AHT11 and AHT19 grown with acetate and sulfur; c electron microphotograph of a positively stained cell of strain AHT11

\section{Results and discussion}

Enrichment and isolation of pure cultures

Two positive anaerobic enrichment cultures with sulfur as electron acceptor were obtained from soda lake sediments at $\mathrm{pH} 10$ and salinity $0.6 \mathrm{M}$ total $\mathrm{Na}^{+}$: with acetate (lake Tanatar-5) and with propionate (Cock Soda Lake) as electron donor. Both cultures actively dissolved sulfur in the form of polysulfide and were dominated by highly motile spirilla. Several rounds of serial dilutions resulted in the isolation of two pure cultures designated strains AHT11 (acetate) and AHT19 (propionate). The purity of the isolates was verified by homogenous morphology and DGGE analysis (a single band with pure sequence).

\section{Cell morphology and identification}

The isolates were spiral shaped highly motile with bipolar tubular flagella (Fig. 1a-c). Colony formation was not observed either inside agar or on the surface of agar plates incubated at anoxic conditions. Liquid cultures at $\mathrm{pH}$ 9-10.5 developed in a peculiar structured way: active

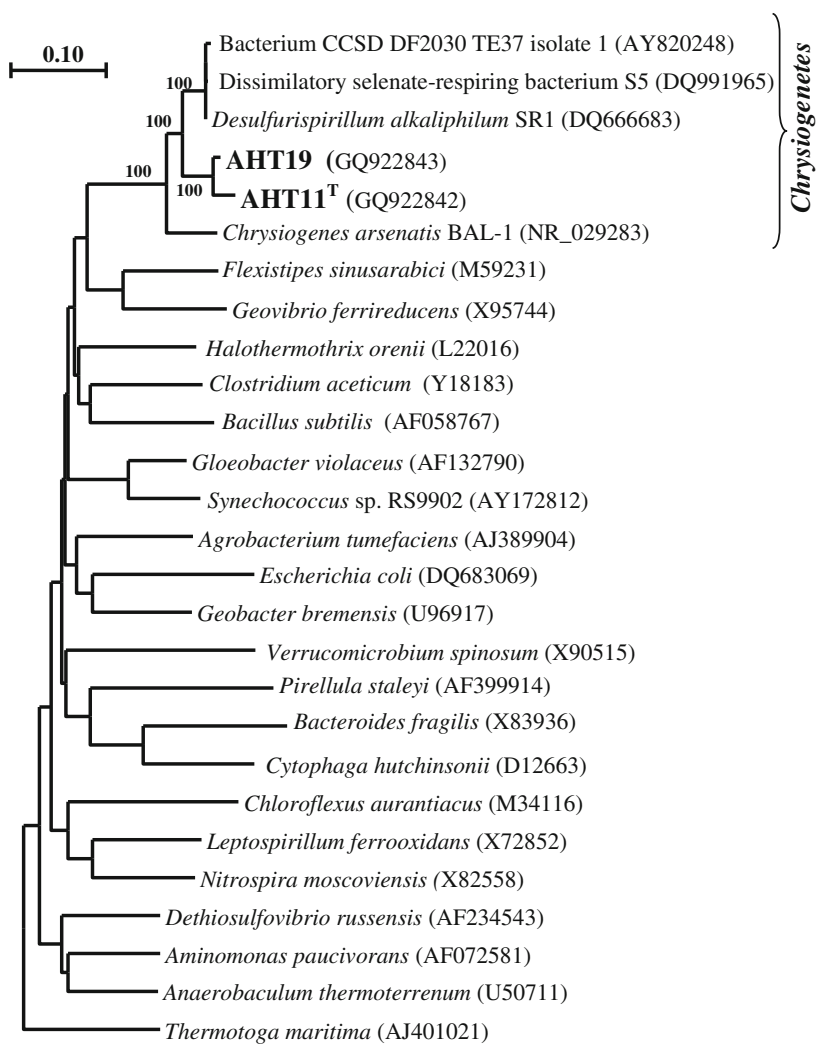

Fig. 2 Phylogenetic position of sulfur-reducing isolates based on 16S rRNA gene sequence analysis. Tree topography and evolutionary distances are obtained by the neighbor-joining method with Jukes and Cantor distances. The scale bar represents 10 nucleotide changes per 100 nucleotides 
dissolution of insoluble elemental sulfur (which was at a large excess) occurred right above the flask bottom with a formation of an intense yellow layer of soluble polysulfide, while the upper part of the culture remained colorless or greenish (Supplementary Figure). This can be explained by the following: the bacteria utilized soluble polysulfide as the actual electron acceptor and produced sulfide which, in turn, immediately attacked the insoluble sulfur on the bottom to form polysulfide. Polysulfide molecules diffusing off the reaction site were reduced completely to sulfide which, in turn, rapidly reacted with sulfur. The greenish color is due to a presence of trisulfide $\left({ }^{-} \mathrm{S}-\mathrm{S}-\mathrm{S}^{-}\right)$formed by an excess of $\mathrm{HS}^{-}$, while the yellow color indicates a presence of longer polysulfides at excess of elemental sulfur.

Phylogenetic analysis (Fig. 2) demonstrated that the isolates are closely related to each other ( $97 \%$ sequence similarity) and belong to the class Chrysiogenetes, a deep bacterial lineage which, at the moment, contains only two valid taxa, Chrysiogenes arsenatis (Macy et al. 1996) and Desulfurispirillum alkaliphilum (Sorokin et al. 2007). The latter is the closest phylogenetic relative of AHT11 and AHT19 (93\% sequence similarity) together with two unclassified anaerobic respirers, i.e., the selenate/arsenatereducing strain $\mathrm{S} 5$ from freshwater sediments (Narasingarao and Haggblom 2007) and an iron-reducing isolate from deep subsurface alkaline strata in China (Zhang et al. 2005).

Comparison of cellular fatty acids in polar lipids demonstrated a general similarity of the profiles in novel isolates and Desulfurispirillum with a domination of C18:1 and C16:0. On the other hand, there was a peculiar difference in the distribution of two isomers of C18:1 in AHT11 and AHT19 (Supplementary Table). Affiliation of the sulfur reducers from soda lakes with Desulfurispirillum alkaliphilum, an acetate-utilizing alkaliphilic sulfur reducer, suggests that such a phenotype is conserved within this phylum. It is also clear that the whole phylum is specialized in ecologically important anaerobic transformations, such as dissimilatory sulfur, nitrate, iron, selenate and arsenate respiration. Direct detection of the members of the Chrysiogenetes in hypersaline soda lakes using a functional phylogenetic marker for arsenate reductase (Hollibaugh et al. 2006; Kulp et al. 2006) indicates that it might be present in significant numbers in alkaline habitats. It is also interesting to note, that the key enzymes responsible for the dissimilatory reduction of arsenate (arr) and polysulfide
Table 1 Phenotypic comparison of soda lake isolates with related bacteria from the class Chrysiogenetes

n.d. not determined

\begin{tabular}{|c|c|c|c|c|}
\hline Characteristic & AHT11 & AHT19 & $\begin{array}{l}\text { Desulfurispirillum } \\
\text { alkaliphilum }\end{array}$ & $\begin{array}{l}\text { Chrysiogenes } \\
\text { arsenatis }\end{array}$ \\
\hline Cell morphology & $\begin{array}{l}\text { Spirillum with } \\
\text { bipolar } \\
\text { flagellum }\end{array}$ & $\begin{array}{l}\text { Spirillum with } \\
\text { bipolar } \\
\text { flagellum }\end{array}$ & $\begin{array}{l}\text { Spirillum with } \\
\text { bipolar flagellum }\end{array}$ & $\begin{array}{l}\text { Vibrio, single } \\
\text { polar flagellum }\end{array}$ \\
\hline Autotrophic growth & - & - & - & - \\
\hline \multicolumn{5}{|l|}{ Electron donors } \\
\hline $\mathrm{H}_{2}$ & + & - & + & - \\
\hline Formate & + & - & - & - \\
\hline $\begin{array}{l}\text { Acetate, pyruvate, lactate } \\
\text { malate, succinate, fumarate }\end{array}$ & + & + & + & + \\
\hline Propionate & + & + & + & - \\
\hline Citrate & - & - & + & - \\
\hline Glycerol & + & - & - & - \\
\hline \multicolumn{5}{|l|}{ Electron acceptors } \\
\hline $\mathrm{O}_{2}$ & - & - & - & - \\
\hline Sulfur (polysulfide) & + & + & + & - \\
\hline $\mathrm{NO}_{3}^{-}, \mathrm{NO}_{2}^{-}$(to $\mathrm{NH}_{3}$ ) & - & - & + & + \\
\hline $\mathrm{N}_{2} \mathrm{O}$ & - & - & - & - \\
\hline Fumarate & - & - & + & - \\
\hline $\mathrm{AsO}_{4}{ }^{2-}$ & + & + & - & + \\
\hline DMSO, $\mathrm{SeO}_{4}{ }^{2-}, \mathrm{Fe}^{3+}, \mathrm{S}_{2} \mathrm{O}_{3}{ }^{2-}$ & - & - & - & - \\
\hline $\begin{array}{l}\text { Oxidation of } \mathrm{HS}^{-} \text {with } \\
\text { nitrate }\end{array}$ & - & - & + & n.d. \\
\hline $\mathrm{pH}$ range (optimum) & $8.5-10.9(10.2)$ & $8.2-10.5(9.8)$ & $8.0-10.2(9.0)$ & Neutrophilic \\
\hline Salt range $\left(\mathrm{M} \mathrm{Na}^{+}\right)$ & $0.2-3.0$ & $0.2-3.0$ & $0.1-2.5$ & Na-independent \\
\hline Habitat & Soda lakes & Soda lakes & Bioreactor & Gold mine \\
\hline
\end{tabular}


(psr) are related within the molybdopterin-containing class of enzymes and, therefore, these two modes of anaerobic respiration might have originated from a common ancestor (Duval et al. 2008).

\section{Growth characteristics}

Both isolates were obligate anaerobes unable to ferment sugars and pyruvate. They utilized a limited number of simple organic electron donors and were unable to grow autotrophically, although strain AHT11 could use $\mathrm{H}_{2}$ and formate as electron donor in presence of acetate as carbon source (Table 1). During growth with sulfur and acetate,

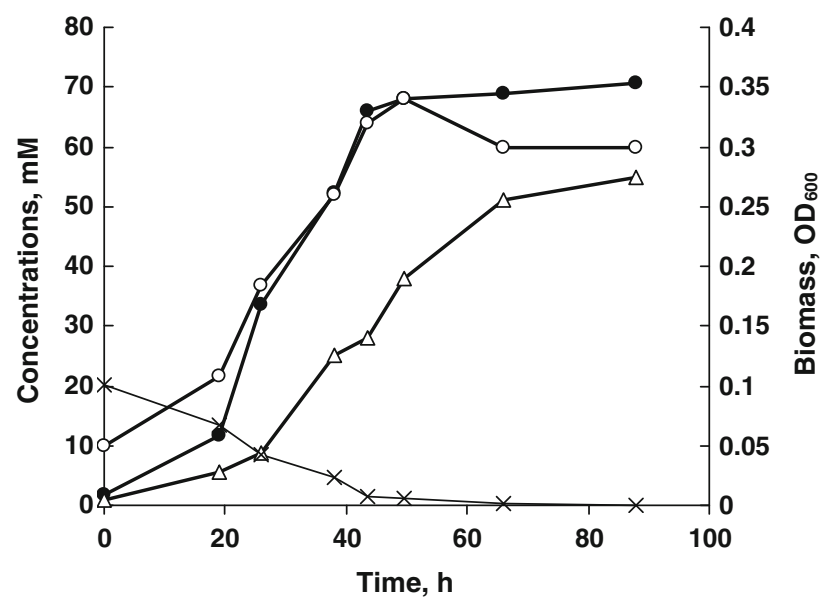

Fig. 3 Anaerobic growth of strain AHT11 at pH 10 and $0.6 \mathrm{M} \mathrm{Na}^{+}$ with acetate and sulfur. Open circles biomass, closed circles total sulfane of sulfide/polysulfide, open triangles zero-valent sulfur dissolved in polysulfide, crosses acetate

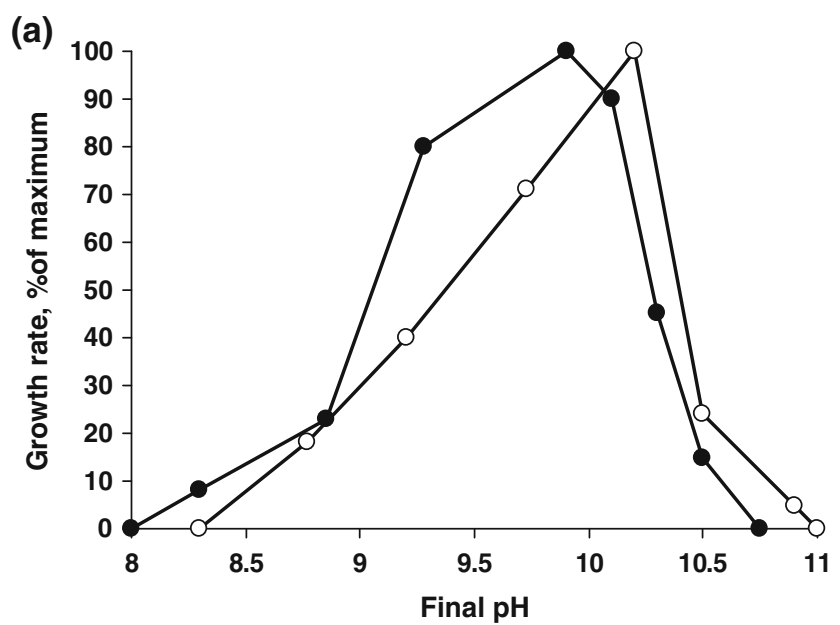

Fig. 4 Influence of $\mathrm{pH}$ at $0.6 \mathrm{M} \mathrm{Na}^{+}$on anaerobic growth (a) and sulfidogenic activity of washed cells (b) of strains AHT11 (open circles) and AHT19 (closed circles) with acetate as electron donor polysulfide was gradually accumulating at extremely high concentrations parallel to sulfur dissolution. As mentioned above, near the solid sulfur surface an intense yellow layer was forming which contained a polysulfide with an average formula $\mathrm{S}_{4}{ }^{2-}$. After mixing with the bulk culture, the color turned greenish due to rapid formation of a lower polysulfide with an average formula $\mathrm{S}_{3}{ }^{2-}$ due to a presence of excess of free $\mathrm{HS}^{-}$. Further fate of polysulfide depended on initial sulfur concentration. When limited, polysulfide started to disappear after complete sulfur dissolution and sulfide was the final product. Acetate consumption was parallel to the biomass and total reduced sulfur formation (Fig. 3). The amount of sulfane formed (70 mM) after complete utilization of $20 \mathrm{mM}$ acetate is close to theoretical maximum $(20 \mathrm{mM}$ acetate $\times 8 \overline{\mathrm{e}}=160 \mathrm{mM} \overline{\mathrm{e}}$; $70 \mathrm{mM}$ sulfane $\times 2 \overline{\mathrm{e}}=140 \mathrm{mM} \overline{\mathrm{e}})$. Maximal specific growth rate with acetate and sulfur at $0.6 \mathrm{M} \mathrm{Na}^{+}$and $\mathrm{pH}$ 10 was 0.11 and $0.07 \mathrm{~h}^{-1}$ in strains AHT11 and AHT19, respectively.

Apart from sulfur, only arsenate could serve as alternative electron acceptor for both isolates at concentrations up to $20 \mathrm{mM}$. However, the growth and arsenate reduction were much poorer than with sulfur being limited to $5 \mathrm{mM}$ arsenate consumption with stoichiometric formation of arsenite. Growth inhibition by the latter might be responsible for this effect.

Influence of $\mathrm{pH}$ and sodium on the growth and activity of the sulfur reducers

With acetate and sulfur both cultures showed obligate alkaliphily, starting to grow only at a $\mathrm{pH}$ above 8.2. On its $\mathrm{pH}$ optimum and highest $\mathrm{pH}$ limit, however, strain AHT11 was more alkaliphilic than strain AHT19 (Fig. 4a).

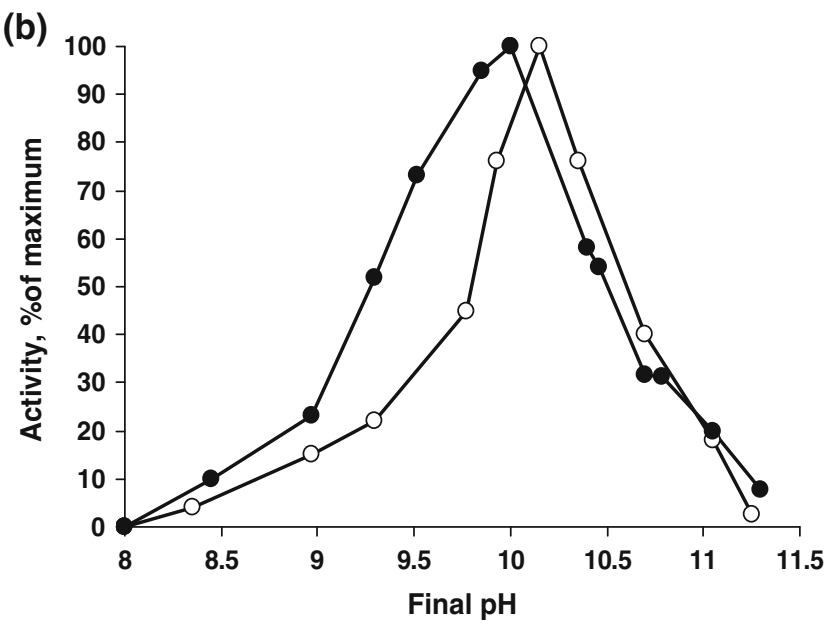

and sulfur as electron acceptor. $100 \%$ activity $=0.93$ and $0.55 \mu \mathrm{mol} \mathrm{HS}{ }^{-} \mathrm{mg}$ protein ${ }^{-1} \mathrm{~min}^{-1}$ in AHT11 and AHT19, respectively 

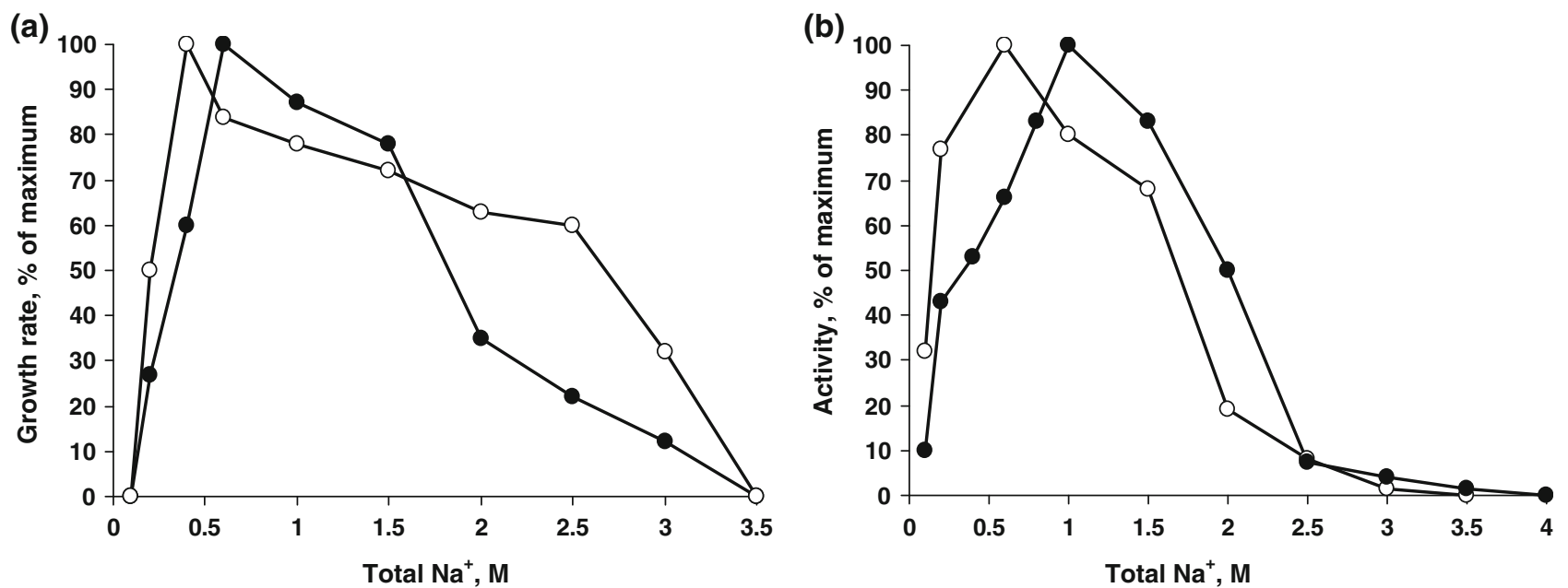

Fig. 5 Influence of sodium carbonate at pH 10 on anaerobic growth (a) and sulfidogenic activity of washed cells (b) of strains AHT11 (open circles) and AHT19 (closed circles) with acetate as electron donor and sulfur as electron acceptor

Sulfidogenic activity of washed cells had very similar strictly alkaliphilic $\mathrm{pH}$ profiles similar to the profiles of growing cells except that in strain AHT19 washed cells tolerated much higher $\mathrm{pH}$ than a growing culture (Fig. $4 \mathrm{~b}$ ). It is necessary to mention that when the initial $\mathrm{pH}$ was above 9 a substantial drop was observed both during growth and during sulfur reduction by washed cells despite a high buffering capacity of the sodium carbonate system. Therefore, the presented profiles are reflecting the final $\mathrm{pH}$ values.

When grown at $\mathrm{pH} 10$ in sodium carbonate-based medium, both strains demanded at least $0.2 \mathrm{M}$ total $\mathrm{Na}^{+}$ and grew up to $3.0 \mathrm{M}$ with an optimum at $0.4-0.6 \mathrm{M}$, which characterizes them as moderately salt-tolerant organisms (Fig. 5a). Washed cells were active at sodium concentrations as low as $0.1 \mathrm{M}$, (but lysed rapidly), and up to 3-3.5 M (Fig. 5b).

Overall, strains AHT11 and AHT19 isolated from sediments of Siberian soda lakes represent the first example of highly specialized haloalkaliphilic anaerobes, whose most important environmental function can be defined as the acetate and propionate sink in anaerobic sediments. The isolates are obligately alkaliphilic and can function within a very broad salinity range. Their sulfur metabolism needs further investigation, since it must be significantly different from well studied sulfur-reducing enzyme system of neutrophiles. From its phylogenetic relatives, such as Deslfurispirillum alkaliphilum and Chrysiogenes arsenatis, the novel isolates can be distinguished by a number of important phenotypic properties (Table 1). Taken together with distinct phylogeny, the novel sulfur-reducing isolates AHT11 and AHT19 are proposed to be assigned into a new genus and species Desulfurispira natronophila within the family Chrysiogenaceae.
Acknowledgments This work was supported by RFBR (10-0400152). We are grateful to E. Detkova for the DNA analysis and to G. Osipov for the cellular fatty acid analysis.

Open Access This article is distributed under the terms of the Creative Commons Attribution Noncommercial License which permits any noncommercial use, distribution, and reproduction in any medium, provided the original author(s) and source are credited.

\section{Appendix 1: Description of Desulfurispira gen. nov.}

Desulfurispira (De.sul.fu.ri.spi'ra. L. pref. de-, from; L.n. sulfur, sulfur; L. fem. n. spira, a coil; N. L. fem. n. Desulfurispira a sulfur-reducing spirillum).

Gram-negative motile spirilla. Obligately anaerobic with respiratory metabolism. Use short-chain fatty acids as electron donors. Do not grow autotrophically. Obligately alkaliphilic and moderately salt-tolerant. Belong to the class Chrysiogenetes. Habitats, soda lakes. The type species is Desulfurispira natronophila.

\section{Appendix 2: Description of Desulfurispira natronophila sp. nov.}

natronophila [na.tro.no.phi'la. N.L. n. natron (arbitrarily derived from the Arabic n. natrun or natron), soda; N.L. pref. natrono-, pertaining to soda; N.L. fem. adj. phila (from Gr. fem. adj. philê), friend, loving; N.L. fem. adj. natronophila soda-loving].

Cells are spiral shaped, $0.3-0.4 \times 2-5 \mu \mathrm{m}$, motile by single bipolar flagella. Gram-negative. Strictly anaerobic, using elemental sulfur, polysulfide and arsenate as electron acceptors. The final products are sulfide and arsenite. 
Obligatory heterotrophic. Utilize short-chain fatty acids, including acetate, propionate, lactate, pyruvate and fumarate as electron donor and carbon source. $\mathrm{H}_{2}$ and formate can be used as electron donor by some strains. Obligately alkaliphilic with a pH range for growth between 8.2 and 10.9 and an optimum at $\mathrm{pH} 9.8-10.2$ and moderately salttolerant with a range from 0.2 to $3.0 \mathrm{M} \mathrm{Na}^{+}$(optimum at 0.4-0.6 M). Mesophilic, with a maximum temperature for growth at $42^{\circ} \mathrm{C}$ and an optimum at $30^{\circ} \mathrm{C}\left(\mathrm{AHT} 11^{\mathrm{T}}\right)$. The predominant fatty acids in the polar membrane lipids include 18:1 and 16:0. The $\mathrm{G}+\mathrm{C}$ content of the genomic DNA is 49.2 for strain $\mathrm{AHT}^{\mathrm{T}} \mathrm{T}^{\mathrm{T}}$ and 51.8 for strain AHT19 mol\% $\left(\mathrm{T}_{\mathrm{m}}\right)$. The type strain is $\mathrm{AHT}_{1}{ }^{\mathrm{T}}$ $\left(\mathrm{DSM} 22071^{\mathrm{T}}=\mathrm{UNIQEM} \mathrm{U} 758^{\mathrm{T}}\right)$. Isolated from sediments of soda lakes in south-western Siberia. The GenBank 16S rRNA gene sequence accession numbers are GQ922842 (strain AHT11 ${ }^{\mathrm{T}}$ ) and GQ922843 (AHT19).

\section{References}

Duval S, Ducluzeau A-L, Nitschke W, Schoepp-Cothenet B (2008) Enzyme phylogenies as markers for the oxidation state of the environment: the case of respiratory arsenate reductase and related enzymes. BMC Evol Biol 8:206

Foti M, Sorokin DY, Lomans B, Mussman M, Zakharova EE, Pimenov NV, Kuenen JG, Muyzer G (2007) Diversity, activity and abundance of sulfate-reducing bacteria in saline and hypersaline soda lakes. Appl Environ Microbiol 73:2093-2100

Gorlenko VM, Namsaraev BB, Kulyrova AV, Zavarzina DG, Zhilina TN (1999) Activity of sulfate-reducing bacteria in the sediments of the soda lakes in south-east Transbaikal area. Microbiology (Moscow, English Translation) 68:580-586

Hedderich R, Klimmek O, Kroëger A, Dirmeier R, Keller M, Stetter KO (1999) Anaerobic respiration with elemental sulfur and with disulfides. FEMS Microbiol Rev 22:353-381

Hollibaugh JT, Budinoff C, Hollibaugh RA, Ransom B, Bano N (2006) Sulfide oxidation coupled to arsenate reduction by a diverse microbial community in a soda lake. Appl Environ Microbiol 72:2043-2049

Janssen AJH, Lens P, Stams AJM, Plugge CM, Sorokin DY, Muyzer G, Dijkman H, van Zessen E, Luimes P, Buisman CJN (2009) Application of bacteria involved in the biological sulfur cycle for paper mill effluent purification. Sci Total Environ 407:13331343

Kulp TR, Hoeft SE, Miller LG, Saltikov C, Murphy JN, Han S, Lanoil B, Oremland RS (2006) Dissimilatory arsenate and sulfate reduction in sediments of two hypersaline, arsenic-rich soda lakes: Mono and Searles Lakes, California. Appl Environ Microbiol 72:6514-6526

Kulp TR, Han S, Saltikov CV, Lanoil BD, Zargar K, Oremland RS (2007) Effects of imposed salinity gradients on dissimilatory arsenate reduction, sulfate reduction, and other microbial processes in sediments from two California soda lakes. Appl Environ Microbiol 73:5130-5137

Lane DJ (1991) 16S/23S rRNA sequencing. In: Stackebrandt E, Goodfellow $M$ (eds) Nucleic acid techniques in bacterial systematics. John Wiley and Sons, Chichester, UK, pp 115-177
Lowry OH, Rosebrough NJ, Farr AL, Randall RJ (1951) Protein measurement with Folin phenol reagent. J Biol Chem 193:265275

Macy JM, Nunan K, Hagen K, Dixon DR, Harbour PJ, Cahill M, Sly LI (1996) Chrysiogenes arsenatis gen. nov., sp. nov., a new arsenate-respiring bacterium isolated from gold mine wastewater. Int J Syst Bacteriol 46:1153-1157

Marmur J (1961) A procedure for isolation of DNA from microorganisms. J Mol Biol 3:208-214

Marmur J, Doty P (1962) Determination of the base composition of deoxyribonucleic acid from microorganisms. J Mol Biol 5:109118

Narasingarao P, Haggblom MM (2007) Identification of anaerobic selenate-respiring bacteria from aquatic sediments. Appl Environ Microbiol 73:3519-3527

Pfennig N, Lippert KD (1966) Über das Vitamin $B_{12}$-Bedürfnis phototropher Schwefelbakterien. Arch Mikrobiol 55:245-256

Plugge CM (2005) Anoxic media design, preparation, and considerations. Methods Enzymol 397:3-16

Scholten JCM, Joye SB, Hollibaugh JT, Murrell JC (2005) Molecular analysis of the sulfate reducing and archaeal community in a meromictic soda lake (Mono Lake, California) by targeting $16 \mathrm{~S}$ rRNA, $m c r \mathrm{~A}$, apsA, and $d s r \mathrm{AB}$ genes. Microbial Ecol 50:29-39

Sörbo B (1957) A colorimetric determination of thiosulfate. Biochim Biophys Acta 23:412-416

Sorokin DY, Gorlenko VM, Namsaraev BB, Namsaraev ZB, Lysenko AM, Eshinimaev BT, Khmelenina VN, Trotsenko YA, Kuenen JG (2004) Prokaryotic communities of the north-eastern Mongolian soda lakes. Hydrobiologia 522:235-248

Sorokin DY, Foti M, Tindall BJ, Muyzer G (2007) Desulfurispirillum alkaliphilum gen. nov. sp. nov., a novel obligately anaerobic sulfur- and dissimilatory nitrate-reducing bacterium from a fullscale sulfide-removing bioreactor. Extremophiles 11:363-370

Sorokin DY, Tourova TP, Henstra AM, Stams AJM, Galinski EA, Muyzer G (2008a) Sulfidogenesis at extremely haloalkaline conditions by Desulfonatronospira thiodismutans gen. nov., sp. nov., and Desulfonatronospira delicata sp. nov.-a novel lineage of Deltaproteobacteria from hypersaline soda lakes. Microbiology (UK) 154:1444-1453

Sorokin DY, Tourova TP, Mussmann M, Muyzer G (2008b) Dethiobacter alkaliphilus gen. nov. sp. nov., and Desulfurivibrio alkaliphilus gen. nov. sp. nov.- two novel representatives of reductive sulfur cycle from soda lakes. Extremophiles 12:431439

Trüper HG, Schlegel HG (1964) Sulfur metabolism in Thiorhodaceae. 1. Quantitative measurements on growing cells of Chromatium okenii. Antonie van Leeuwenhoek 30:225-238

van de Peer Y, de Wachter R (1994) TREECON for Windows: a software package for the construction and drawing of evolutionary trees for the Microsoft Windows environment. Comput Appl Biosci 10:569-570

Zhang G, Dong H, Xu X, Zhao D, Zhang C (2005) Microbial diversity in ultra-high-pressure rocks and fluids from the Chinese Continental Scientific Drilling project in China. Appl Environ Microbiol 71:3213-3227

Zhilina TN (2007) Chemotrophic anaerobes of microbial communities of soda lakes. In: Transactions of the Winogradsky Institute of Microbiology, V XIV, Nauka, Moscow, pp 206-216 (in Russian)

Zhilina TN, Zavarzin GA, Rainey FA, Pikuta EN, Osipov GA, Kostrikina NA (1997) Desulfonatronovibrio hydrogenovorans gen. nov., sp. nov., an alkaliphilic, sulfate-reducing bacterium. Int J Syst Bacteriol 47:144-149 